\title{
Hydrogen Peroxide Measurements by MISFET and LET Structures with Rear Porous Silicon Layer and Metallic Nanoparticles
}

\author{
O. Yu. Kutova, ORCID https://orcid.org/0000-0003-1720-9700 \\ e-mail oksana03fel@gmail.com \\ Electronic engineering department \\ National technical university of Ukraine "Igor Sikorsky Kyiv Polytechnic Institute" \\ Kyiv, Ukraine
}

T. Yu. Obukhova, PhD, ORCID https://orcid.org/0000-0001-6415-4461

e-mail t.y.obukhova@gmail.com

M. G. Dusheiko, ORCID https://orcid.org/0000-0003-2267-6637

e-mail mgd61@ukr.net

B. O. Loboda, ORCID https://orcid.org/0000-0003-1704-8265

e-mail loboda9111@ukr.net

Microelectronic department

National technical university of Ukraine "Igor Sikorsky Kyiv Polytechnic Institute"

Kyiv, Ukraine

\section{T. I. Borodinova, PhD, ORCID https://orcid.org/0000-0001-6070-8893 \\ e-mail borodinova@ua.fm \\ F. D. Ovcharenko Institute of Biocolloid Chemistry NAS Ukraine \\ Kyiv, Ukraine}

S. V. Tkach, PhD, ORCID https://orcid.org/0000-0001-8426-4879

e-mail tkachs@nas.gov.ua

V.Bakul Institute for Superhard Materials, NASU

Kyiv, Ukraine

\begin{abstract}
In the paper hydrogen peroxide MISFET and LET sensor performance is investigated. As hydrogen peroxide is a product of many chemical reactions, especially biological reactions, peroxide sensors are now widely used for detection of another. In this work, a combination of two nanostructures that are now used for hydrogen peroxide detection - porous silicon and metal nanoparticles was used.

A MISFET (metal-insulator-semiconductor field effect transistor) was chosen as the basic sensor but unlike conventional FET sensors sensitive area was formed on the rear side of the sensor. In the aim to simplify sensor structure a LET (lighteffect transistor) with sensitive area on the rear side was also tested. LET structure was produced by the same technology as FET, but then subgate system was removed by chemical etching. Porous silicon was formed by metal-assisted chemical etching (MACE) that consists of two stages. During the first stage, metallic nanoparticles are deposited on the surface by chemical or physical deposition. During second one these particles become catalysts of chemical reaction and pores are formed under them. Pore shape and density depend on both stages conditions.

Formation of porous silicon on the rear side leads to changes of substrate charge and influence gate-source curve as well as drain-source curve. Drain current for FET with an active area is lower due to the negative charge accumulated in porous silicon thanks to high tie connections concentration. Dependence of LET drain current on LED intensity (current) is almost linear and drain-source curves are similar to FET structure ones. FET samples with porous silicon/Pt and LET samples with porous silicon/Ag both show more stable and well-defined dependence of drain current on hydrogen peroxide concentration then samples without porous layer. All sensors have saturation of drain current from concentrations of hydrogen peroxide about $0.5-1 \%$ and dependence on concentration is first order exponential decay, obviously due to saturation of working area by reaction products or heating effect of hydrogen peroxide decomposition. In concentration range up to $0.3 \%$
\end{abstract}


hydrogen peroxide best sensitivity was demonstrated by LET sensor $(574 \mu \mathrm{A} / \%)$, for FET sensor sensitivity is about $6 \mu \mathrm{A} / \%$ for MISFET without active area and about $8.3 \mu \mathrm{A} / \%$ for MISFET with active area. As Ag and Pt catalyst hydrogen peroxide decomposition, sensors with metal nanoparticles shows quicker reaction (maximum response less than in 3 minutes). To ensure accuracy and precision of measurements temperature and illumination of active area dependences of drain current should be taken into account. MISFET with porous silicon demonstrates typical for silicon structures exponential decay dependence of drain current on luminous flux and quasi-linear dependence on temperature Slopes are $34 \mu \mathrm{A} / \mathrm{lm}$ and $6.46 \mu \mathrm{A} /{ }^{\circ} \mathrm{C}$ respectively.

Hydrogen peroxide sensor with porous silicon shows good performance in both configuration - as MISFET and as LET structure. MISFET structure is more adjustable but have lower sensitivity (about $8 \mu \mathrm{A} / \%$ ) while LET structure is more simple and sensitive (up to $500 \mu \mathrm{A} / \%$ ). Use of both $\mathrm{Ag}$ and Pt nanoparticles decrease response time of sensor to 2-3 minutes. Ref 21, fig 17

Keywords— porous silicon; MISFET sensor; Pt nanoparticles, LET sensor, Ag nanoparticles

\section{INTRODUCTION}

$\mathrm{H}_{2} \mathrm{O}_{2}$ is a product of many chemical reactions, especially biological reactions, so peroxide sensors are now widely used for detection of another chemical [1] and the need of cheap and reliable sensors remains high.

Nanoparticles of noble metals are used in sensor applications [1]-[5] as active structure as well as a catalyst. Most common metals used for this purpose are Pt, $\mathrm{Ag}$, and Au. Metal choice is determined by the substance to be identified and by sensor type [2].

As we concentrated on hydrogen peroxide detection and Ag and Pt were chosen because of its catalyst properties and inactivity against Si substrate.

On the other hand use of porous silicon increase active area surface and porous layer by itself can be used as detection structure of the sensor [6]-[12].

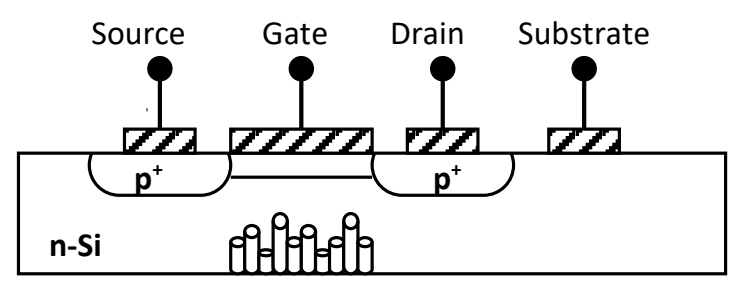

por-Si + Pt

Fig. 1. FET sensor structure [17]

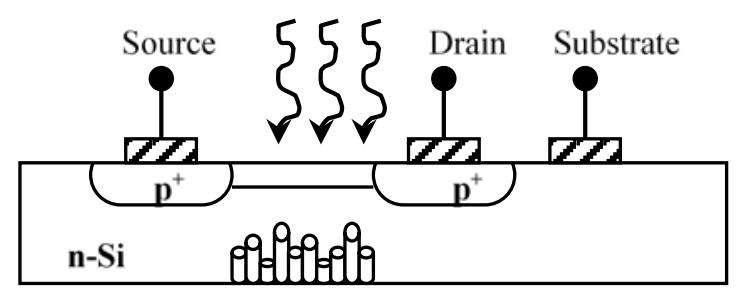

por-Si + Ag
In this work, a combination of two nanostructures porous silicon and metal nanoparticles was used in the aim to determine best combination and technological process for hydrogen peroxide sensor formation.

There is two main types of hydrogen peroxide sensors - electrochemical sensors [13]-[15] and FET-based sensors [16],[17]. First type of sensors needs to be immersed in solution that is not always possible but the second type needs for detection only a very little amount of solution (less than $0.1 \mathrm{ml}$ ) that is more useful for in-field detection.

In this work a MISFET (metal-insulator-semiconductor field effect transistor) was chosen as the basic sensor but, unlike conventional FET sensors, sensitive area was formed on the rear side of the sensor [17].

In the aim to simplify sensor structure a LET (lighteffect transistor) with sensitive area on the rear side was also tested.

\section{SAMPLE PREPARATION}

\section{A. FET and LET structure}

The sensor is based on the p-channel field-effect transistor of metal-insulator-semiconductor (MIS) type (fig 1). FET was produced on silicon wafers doped with phosphorous (n-type), resistance $4.5 \Omega / \mathrm{m}^{2}$, orientation (111), thickness $450 \mu \mathrm{m}$. As subgate insulator system $\mathrm{SiO}_{2}-\mathrm{CeO}_{2}\left(\mathrm{~d}_{\mathrm{SiO} 2}=10 \mathrm{~nm}, \mathrm{~d}_{\mathrm{CeO} 2}=50 \mathrm{~nm}\right)$ was used. Silicon dioxide was produced by thermal oxidation and a thin film of cerium oxide was deposited by "oxidation of metallic mirror" method. Ohmic contacts to p-Si were made with $\mathrm{Al}$

LET structure (fig.2) was produced by the same technology as FET above, but then subgate system was removed by chemical etching.

\section{B. Nanoparticles formation and deposition}

Platinum nanoparticles were produced by chemical reduction of $\mathrm{PtCl}_{6}{ }^{2-}$ ions by ascorbic acid. In a mixture of water solutions $\mathrm{H}_{2} \mathrm{PtCl}_{6} \cdot 6 \mathrm{H}_{2} \mathrm{O}\left(\mathrm{C}_{\mathrm{Pt}}=200 \mathrm{mg} / \mathrm{dm}^{3}\right)$ and $\mathrm{C}_{6} \mathrm{H}_{8} \mathrm{O}_{6}\left(5 \cdot 10^{-2}\right.$ moles $\left./ \mathrm{dm}^{3}\right)$ during 24 hours at $40^{\circ} \mathrm{C}$ quasispherical particles with average diameter of $26 \mathrm{~nm}$ are formed [15] Particles dimensions and sharp are almost regular as can be seen on SEM image of colloid (fig. 3). After spin coating deposition on the silicon surface Pt nanoparticles cover surface almost regulary and form linear-like conglomerates of few $\mu \mathrm{m}$ long (fig. 4)

Fig. 2. LET sensor structure 


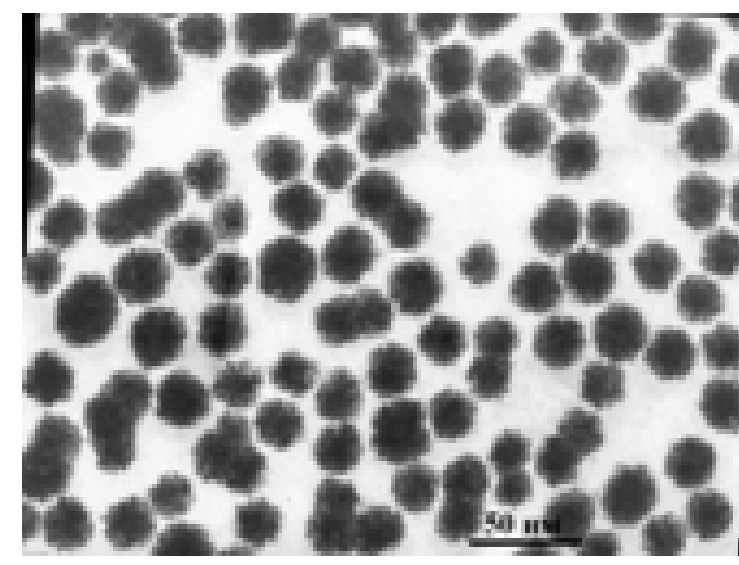

Fig. 3. SEM (JEM 2000FXII) image of Pt nanoparticles

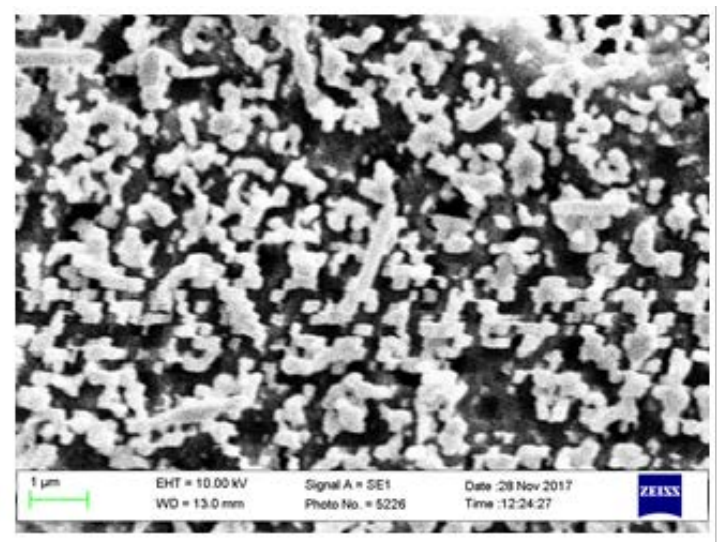

Fig. 4. SEM image of active area surface with Pt nanoparticles

Argentum nanoparticles were formed directly on the silicon surface from $\mathrm{HF}+\mathrm{AgNO}_{3}$ solution. Reaction time varied from 3 to 10 seconds.

Ag nanoparticles sharp and distribution are irregular; dimensions vary from few $\mu \mathrm{m}$ to hundred nm (fig. 5)

\section{Metal-assisted chemical etching}

Metal-assisted chemical etching (MACE) consists of two stages. During the first stage, metallic nanoparticles are deposited on the surface by chemical or physical deposition. During second one these particles become catalysts of chemical reaction and pores are formed under them. Pore shape and density depend on both stages conditions [18]. MACE process generally is more controlled than conventional porous silicon formation.

Porous silicon active structure was formed on the rear side of transistor.

First, nanoparticles were applied on silicon surface by spin coating $(\mathrm{Pt})$ or chemical deposition (Ag) and after this metal-assisted chemical etching in $5 \mathrm{M} \mathrm{HF}+0,3 \mathrm{M}$ $\mathrm{H} 2 \mathrm{O} 2$ solution was performed at room temperatures. In this way, etching occurs under nanoparticles in (100) direction. [19, 20] (fig. 6)

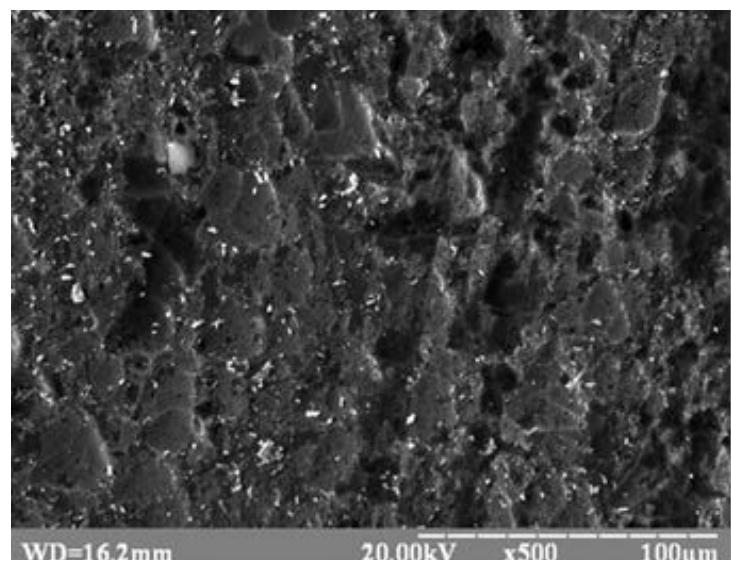

Fig. 5. SEM image of active area surface with Ag nanoparticles

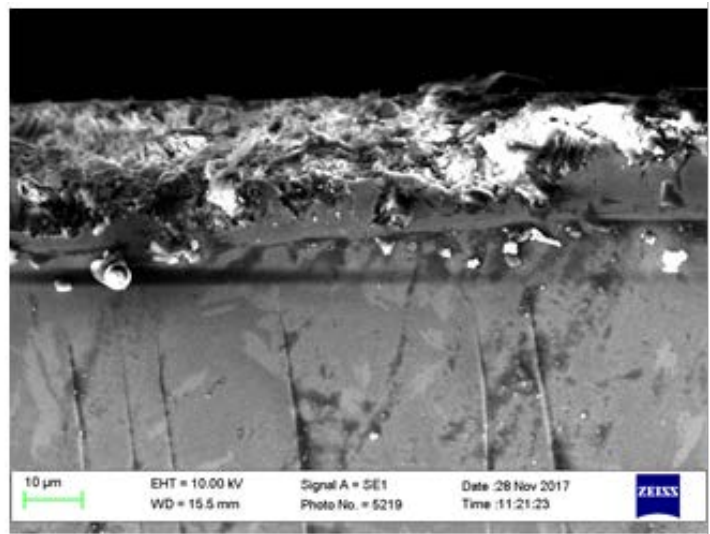

Fig. 6. SEM image of active area cross section

\section{RESULTS AND DISCUSSION}

\section{A. I-V curves}

In the work, two FET structures were compared: a MISFET with porous silicon and $\mathrm{Pt}$ particles and a MISFET without active area.

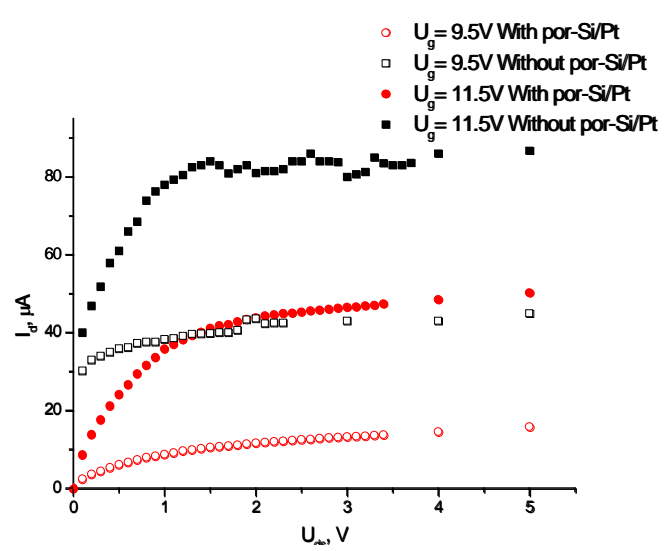

Fig. 7. Source-drain curves

(c) (7) Лобода Б. О., Бородінова Т. І., Ткач С.В. 


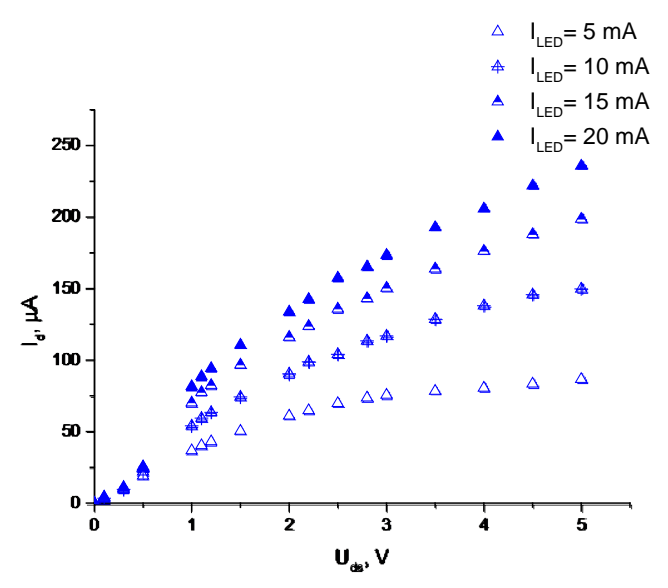

Fig. 8. Source-drain curves of LET at different LED intensity (current)

Formation of porous silicon on the rear side leads to changes of substrate charge and influence gate-source curve as well as drain-source curve (fig. 7). Drain current for FET with an active area is lower due to the negative charge accumulated in porous silicon thanks to high tie connections concentration.

Unlike FET structure LET structure drain current is controlled by light intensity. In this work a blue LED with intensity 6000-8000 mcd and wavelength $450 \mathrm{~nm}$ was used for gate control. Dependence of LET drain current on LED intensity (current) is almost linear and drainsource curves are similar to FET structure ones (fig. 8)

\section{B. Concentration dependences}

FET samples with porous silicon/Pt (fig 9) and LET samples with porous silicon/Ag (fig. 10) both show more stable and well-defined dependence of drain current on hydrogen peroxide concentration then samples without porous silicon (fig.11). Optimal conditions for concentration measurements are: $\mathrm{U}_{\mathrm{ds}}=3 . .5 \mathrm{~V}, \mathrm{U}_{\mathrm{g}}=12 \mathrm{~V}$ ( FET) or $\mathrm{I}_{\mathrm{LED}}=20 \mathrm{~mA}(\mathrm{LET})$

All sensors have saturation of drain current from concentrations of hydrogen peroxide about $0.5-1 \%$ (fig. 14)

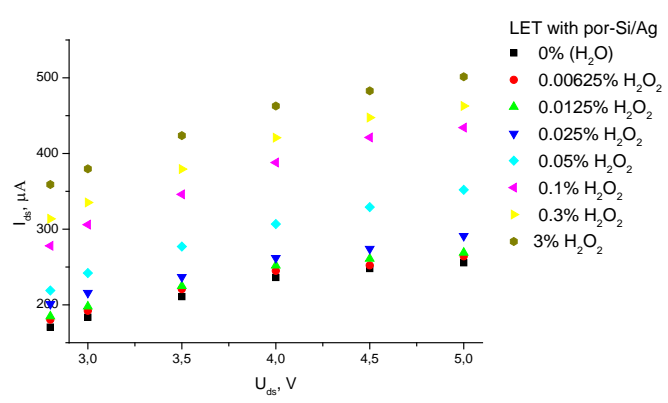

Fig. 10. Source-drain curves of LET with active area for different concentrations of $\mathrm{H}_{2} \mathrm{O}_{2}$

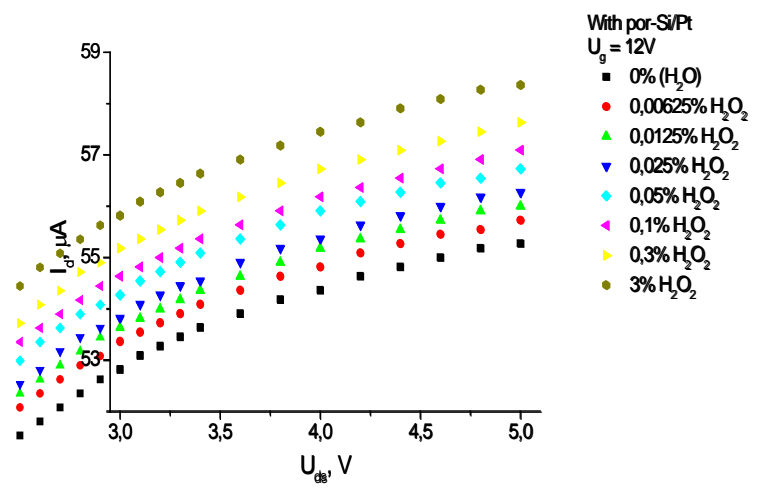

Fig. 9. Source-drain curves of MISFET with active area for different concentrations of $\mathrm{H}_{2} \mathrm{O}_{2}$

and dependence on concentration is first order exponential decay $y=a e^{-\frac{x}{b}}+c$, obviously due to saturation of working area by reaction products or heating effect of hydrogen peroxide decomposition.

In concentration range up to $0.3 \% \mathrm{H}_{2} \mathrm{O}_{2}$ best sensitivity was demonstrated by LET sensor $(574 \mu \mathrm{A} / \%)$, for FET sensor sensitivity is about $6 \mu \mathrm{A} / \%$ for MISFET without active area and about $8.3 \mu \mathrm{A} / \%$ for MISFET with active area.

\section{Time dependences}

Time dependances of drain current allows to evaluate response time of sensor and influence of catalysts (fig. 13). As Ag and Pt catalyst $\mathrm{H}_{2} \mathrm{O}_{2}$ decomposition, sensors with metal nanoparticles shows quicker reaction (maximum response less than in 4 minutes). There is no significant difference between response time with Ag and Pt nanoparticles but signal of LET sensor with Ag nanoparticles remain more stable after maximum (deviation do not exceed $0.1 \%$ )

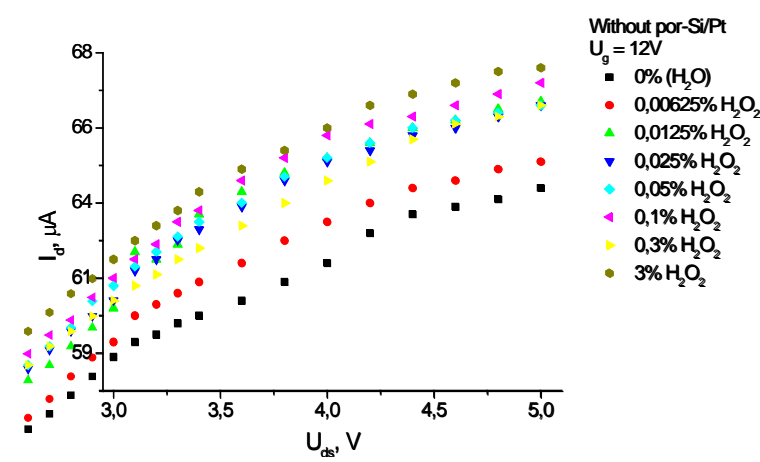

Fig. 11. Source-drain curves of MISFET without active area for different concentrations of $\mathrm{H}_{2} \mathrm{O}_{2}$ 


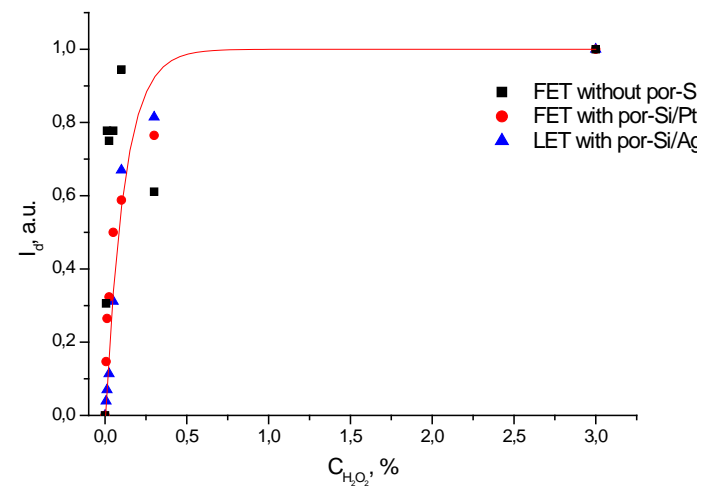

Fig. 12 Normalized source-drain current dependence on $\mathrm{H}_{2} \mathrm{O}_{2}$ concentration $(\mathrm{Uds}=4 \mathrm{~V}, \mathrm{Ug}=12 \mathrm{~V}$ or $\mathrm{ILED}=20 \mathrm{~mA})$

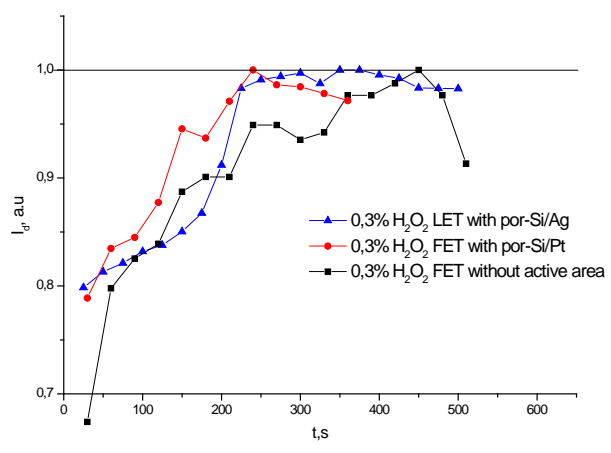

Fig. 13. Normalized source-drain current dependence on time at $\mathrm{H}_{2} \mathrm{O}_{2}$ concentration $0.3 \%$ (Uds $=4 \mathrm{~V}, \mathrm{Ug}=12 \mathrm{~V}$ or ILED=20mA)

\section{Temperature and illumination dependences}

To ensure accuracy and precision of measurements temperature and illumination of active area dependences of drain current should be taken into account. For in-field sensors temperature sensor should be incorporated into structure and measurements must be performed in dark.

MISFET with porous silicon demonstrates typical for silicon structures exponential decay dependence of drain current on luminous flux (fig. 14) and quasi-linear dependence on temperature (fig. 15). Slopes are $34 \mu \mathrm{A} / \mathrm{lm}$ and $6.46 \mu \mathrm{A} /{ }^{\circ} \mathrm{C}$ respectively.

\section{CONCLUSION}

Both MISFET and as LET structures can be used as hydrogen peroxide sensor. Use of both Ag and Pt nanoparticles decrease response time of sensor to 2-3 minutes. MISFET structure with Pt nanoparticles is more controlled by gate voltage but have lower sensitivity (about $8 \mu \mathrm{A} / \%$ ) and time stability (up to $0.2 \%$ ); while LET structure is more simple, stable and sensitive (up to $500 \mu \mathrm{A} / \%$ ). Further investigation is needed to clarify is this difference is due to sensor structure or to nanoparticles material.

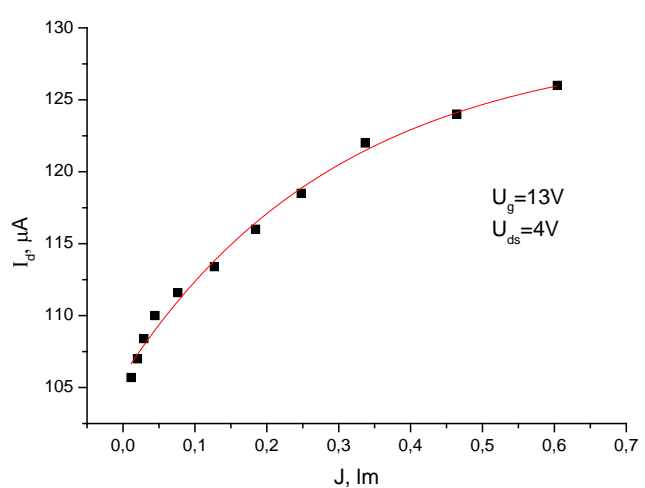

Fig. 14. Drain current dependece on luminous flux of MISFET with active area

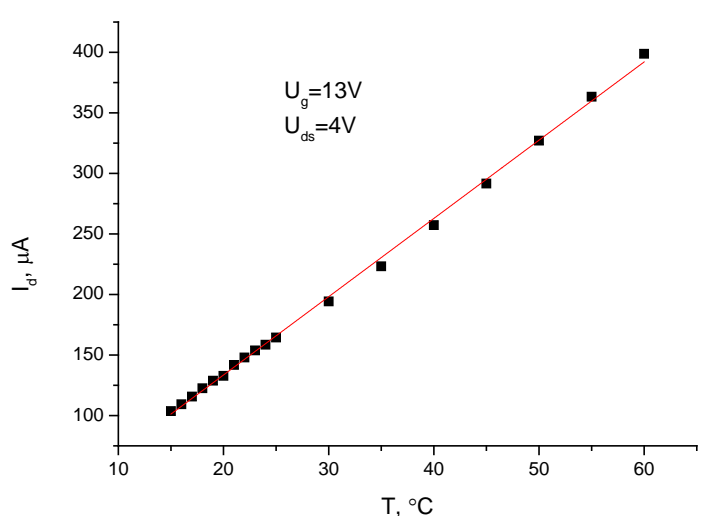

Fig. 15. Drain current dependece on temperature of MISFET with active area

\section{REFERENCES}

1. Chen, S., Yuan, R., Chai, Y. et "Electrochemical sensing of hydrogen peroxide using metal nanoparticles: a review” Microchim Acta vol. 180, p. 15., 2013 DOI: 10.1007/s00604-012-0904-4

2. Yuan Zhang, "Decoration of $\mathrm{ZnO}$ nanowires with Pt nanoparticles and their improved gas sensing and photocatalytic performance" Nanotechnology, vol. 21, p. 285501, 2010 DOI: $10.1088 / 0957-$ 4484/21/28/285501

3. Luo, X., Morrin, A., Killard, Anthony J. and Smyth, Malcolm R., "Application of Nanoparticles in Electrochemical Sensors and Biosensors”. Electroanalysis, vol. 18, pp. 319-326, 2006 DOI: 10.1002 /elan.200503415

4. Wang, Q., Zheng, J. "Electrodeposition of silver nanoparticles on a zinc oxide film: improvement of amperometric sensing sensitivity and stability for hydrogen peroxide determination” Microchim Acta vol. 169, p.361, 2010 DOI: 10.1007/s00604-010$\underline{0356-7}$

5. Wang, L., Zhu, H., Hou, H. "A novel hydrogen peroxide sensor based on Ag nanoparticles electrodeposited on chitosan-graphene oxide/cysteamine-modified gold electrode” J Solid State Electrochem, vol.16, p.1693, 2012 DOI: $10.1007 /$ s10008-011-1576-4

6. T. Jalkanen, J. Tuura, E. Makila, J. Salonen "Electro-optical porous silicon gas sensor with enhanced selectivity" Sensors and Actuators B vol.147, pp. 100-104, 2010 DOI: $10.1016 /$ j.snb.2010.03.005 
7. M.V. Chursanova, L.P. Germash, V.O. Yukhymchuk, V.M. Dzhagan, I.A. Khodasevich, D. Cojoc “Optimization of porous silicon preparation technology for SERS applications" Applied Surface Science vol. 256, pp.3369-3373, 2010 DOI: $10.1016 /$ j.apsusc.2009.12.036

8. Han-Jung Kim, Young-You Kim, Ki-Won Lee "Multiparametric sensor based on DBR porous silicon for detection of ethanol gas" Current Applied Physics vol. 10 pp. 181 - 183, 2010, DOI: $10.1016 /$ j.cap.2009.04.020

9. Saakshi Dhanekar, S. S. Islam, T. Islam, A. K. Shukla, Harsh "Organic vapour sensing by porous silicon: Influence of molecular kinetics in selectivity studies” Physica E, vol. 42, pp. 1648 1652, 2010 DOI: 10.1016/j.physe.2010.01.017

10. J. Diana, V. Vrkoslav, I. Jelinek "Recognition enhancement of oxidized and methyl-10-undecenoate functionalized porous silicon in gas phase photoluminescence sensing” Sensors and Actuators $B$ vol.147, pp. 406 - 410, 2010, DOI: 10.1016/i.snb.2010.03.073

11. L. N. Acquaroli, R. Urteaga, R. R. Koropecki "Innovative design for optical porous silicon gas sensor" Sensors and Actuators B: Chemical, vol.149, is.1. pp. 189 - 193, 2010, DOI: $10.1016 /$ j.snb.2010.05.065

12. V. A. Skryshevsky "Basics of MIS-type gas sensors with thin nanoporous silicon" Electronics and Nanotechnology (ELNANO), 2014 IEEE 34th International Conference 15-18 April 2014 Kyiv. - pp. 78-82, 2014 DOI: 10.1109/ELNANO.2014.6873967

13. Ali A. Ensafi, Fatemeh Rezaloo, B. Rezaei, Electrochemical sensor based on porous silicon/silver nanocomposite for the determination of hydrogen peroxide Sensors and Actuators B: Chemical, vol. 231, pp. 239-244, 2016, DOI: 10.1016/j.snb.2016.03.018

14. Ensafi, M. Mokhtari Abarghoui, B. Rezaei, Electrochemical determination of hydrogen peroxide using copper/porous silicon based non-enzymatic sensor // Sensors and Actuators B: Chemical, vol. 196, pp. 398-405, 2014 DOI: $\underline{10.1016 / j . s n b .2014 .02 .028}$

Надійшла до редакції 11 вересня 2018 р.
15. Al-Hardan, N.H.; Abdul Hamid, M.A.; Shamsudin, R. AL-Khalqi, E.M.; Kar Keng, L.; Ahmed, N.M. "Electrochemical Hydrogen Peroxide Sensor Based on Macroporous Silicon” Sensors, vol.18, p.716, 2018 DOI: 10.3390/s18030716

16. M. Dusheiko, V. Ilchenko, T. Obukhova and M. Stepanova, "Sensors on FET with porous silicon," 2017 IEEE 37th Internationa Conference on Electronics and Nanotechnology (ELNANO), Kiev, 2017, pp. 162-164, 2017

DOI: 10.1109/ELNANO.2017.7939739

17. O. Kutova, M. Dusheiko, T. Obukhova, V. Tymofeev, N. Maksimchuk, T. Borodinova " $\mathrm{H}_{2} \mathrm{O}_{2}$ sensor based on FET with active layer in substrate area" Sensor Electronics and Microsystem Technologies, vol 14, No 4, pp 5-12, 2017

18. V. Estela-Lupis, T. Borodinova, I. Urkova "Extracellular biomineralization and gold and platinum nano- and microcrystallytes synthesis in polysaccharides wather solutions” in Colloidchemical basis of nanoscience Kyiv: Akademperiodika, 2005.

19. C. Chartier, S. Bastide, C. Levy-Clement "Metal-assisted wet chemical etching of crystalline silicon” Proceedings of the 22nd European Photovoltaic Solar Energy Conference, 3-7 September 2007, Milan, Italy, pp. 1231-1234, 2007, DOI: 10.1016/j.nantod.2014.04.013

20. Zhipeng Huang, Xuanxiong Zhang, Manfred Reiche, Lifeng Liu, Woo Lee, Tomohiro Shimizu, Stephan Senz, and Ulrich Gösele, Extended arrays of vertically aligned sub-10 nm diameter [100] Si nanowires by metal-assisted chemical etching, Nano Letters, vol. 8, No. 9, pp. 3045-3051, 2008 DOI: 10.1021/nl802324y

21. Zhipeng Huang, Nadine Geyer, Peter Werner, Johannes de Boor, Ulrich Gösele, Metal-Assisted Chemical Etching of silicon: A Review, Adv. Mater, vol.23, pp. 285-308, 2011 DOI: 10.1002/adma.201001784

\section{Сенсори на польових та фототранзисторах 3 металевими наночастинками та пористим кремнієм}

Кутова О. Ю., ORCID https://orcid.org/0000-0003-1720-9700

e-mail oksana03fel@gmail.com

Кафедра електронної інженерії

Національний технічний університет України «Київський політехнічний інститут імені Ігоря Сікорського» Київ, Україна

Обухова Т. Ю., к.т.н, ORCID https://orcid.org/0000-0001-6415-4461

e-mail t.y.obukhova@gmail.com

Душейко М. Г., ORCID https://orcid.org/0000-0003-2267-6637

e-mail mgd61@ukr.net

Лобода Б. О., ORCID https://orcid.org/0000-0003-1704-8265

e-mail loboda9111@ukr.net

Кафедра мікроелектроніки

Національний технічний університет України «Київський політехнічний інститут імені Ігоря Сікорського» Київ, Україна 
Бородінова Т. I., к.т.н., ORCID https://orcid.org/0000-0001-6070-8893

e-mail borodinova@ua.fm

Інститут біоколоїдної хімії ім.. Ф.Д. Овчаренко, НАНУ

Київ, Україна

Ткач C.B., к.T.H., ORCID https://orcid.org/0000-0001-8426-4879

e-mail tkachs@nas.gov.ua

Інститут надтвердих матеріалів ім. В. Бакуля, НАНУ

Київ, Україна

Реферат-В статті досліджуються два типи сенсорів перекису водню - на основі польового транзистора та на основі фото транзистора. В обох випадках чутлива область розташовувалась на тильній стороні кремнісвої підкладки і складалася 3 шару пористого кремнію 3 наночастинками металів (платини або срібла). Пористий шар отримувався шляхом хімічного травлення в присутності металів. Сенсори $з$ пористим кремнісм демонструють достатню чутливість в обох конфігураціях. Польова структура с більш керованою, проте має нижчу чутливість (8 $\mu$ А/\%), тоді як фототранзисторна структура є більш простою та чутливою (до $500 \mu \mathrm{A} / \%)$. Використання срібних та платинових наночастинок зменшує час відгуку сенсора до 2-3 хвилин.

Бібл. 21, рис. 15.

Ключові слова - пористий кремній; МДН-транзистор; фототранзистор; наночастинки срібла; наночастинки платини

УДК 620.3

\section{Сенсоры на полевих та фототранзисторах с металлическими наночастицами та пористым кремнием}

Кутовая О. Ю., ORCID https://orcid.org/0000-0003-1720-9700

e-mail oksana03fel@gmail.com

Кафедра электронной инженерии

Национальный технический университет Украины «Киевский политехнический институт имени Игоря Сикорского»

Киев, Украина

Обухова Т. Ю., к.т.н, ORCID https://orcid.org/0000-0001-6415-4461

e-mail t.y.obukhova@gmail.com

Душейко М. Г., ORCID https://orcid.org/0000-0003-2267-6637

e-mail mgd61@ukr.net

Лобода Б. О., ORCID https://orcid.org/0000-0003-1704-8265

e-mail loboda9111@ukr.net

Кафедра микроелектроники

Национальный технический университет Украины «Киевский политехнический институт имени Игоря Сикорского»

Киев, Украина

Бородинова Т. И., к.т.н., ORCID https://orcid.org/0000-0001-6070-8893

e-mail borodinova@ua.fm

Институт биоколлоидной химии им.. Ф.Д. Овчаренко, НАНУ

Киев, Украина 
Ткач C.B., к.т.н., ORCID https://orcid.org/0000-0001-8426-4879

e-mail tkachs@nas.gov.ua

Институт сверхтвердых материалов им. В. Бакуля, НАНУ

Киев, Украина

Реферат-В статье исследуется два типа сенсоров перекиси водовода - на основе полевого транзистора и на основе фототрензистора. В обеих случаях чувствительная область расположена на тыльной стороне кремниевой подкладки и состояла из слоя пористого кремния с наночастичками металлов (платины или серебра). Пористый слой был получен путем химического травления в присутствии металлов. Сенсоры с пористым кремнием демонстрируют достаточную чувствительность в обеих конфигурациях. Полевая структура болем управляема, но имеет болем низкую чувствительность $(8 \mu \mathrm{A} / \%)$, тогда как фотостранзисторная структура более простая и чувствительна (до $500 \mu \mathrm{A} / \%$ ). Использование серебряных и платинових наночастиц уменьшает время отклика сенсора до 2-3 минут.

Библ. 21, рис. 15

Ключевые слова - пористый кремний; МДП-транзистор; фототранзистор; наночастички среребра; наночастички платинь 